\title{
Dezavantajlı Gruptaki Çocuklarla Eğitim Süreci: Sınıf Öğretmeni Adaylarının Görüşleri*
}

\author{
Ömür GÜRDOĞAN BAYIR ${ }^{* *}$
}

\begin{abstract}
Dezavantajlı Gruptaki Çocuklarla Eğitim Süreci: Sınıf Öğretmeni Adaylarının Görüşleri

Özet

Toplumda yetersiz koşullarda içinde yaşayan ve bu koşullara bağlı olarak bazı yetersizliklerle baş etmek durumunda kalan gruplar dezavantajlı gruplar olarak tanımlanabilir. Günümüzde bu grupların eğitim sorunları da ele alınması gereken önemli bir sorundur. Bu bağlamda bu grupta yer alan çocukların eğitsel gereksinimlerinin dikkate alınması bakımından sınıf öğretmeni adaylarının bu konuya ilişkin farkındalığı önem taşımaktadır. Söz edilen önemden yola çıkarak bu araştırmanın amacı, sınıf öğretmeni adaylarının dezavantajlı grupta yer alan çocukların eğitim sürecine ilişkin görüşlerini belirlemektir. Araştırma betimsel nitelik taşıyan bir araştırmadır. Araştırmanın katılımcılarını ölçüt örnekleme dayalı olarak seçilen sınıf öğretmeni adayları oluşturmaktadır. Araştırmanın verileri yapılandırılmış görüşme formu aracılığıyla toplanmış ve tümevarım analizi ile analiz edilmiştir. Araştırmada sınıf öğretmeni adaylarının dezavantajlı gruplarla eğitim sürecine ilişkin görüşleri aile, çocuk, kurum/kişiler ve öğretim etkinlikleri temaları çerçevesinde ele alınmıştır.
\end{abstract}

Anahtar Kelimeler: Dezavantajlı Gruplar, Risk Grubu Altındaki Çocuklar, Sınıf Öğretmeni Adayı

\author{
Education Process With Children in Disadvantage Gro- \\ ups: Views Of Preservice Elementary School Teachers \\ Abstract
}

Groups that are living in insufficient conditions in society and who have to cope with some deficiencies depending on these conditions can be defined as disadvantaged groups. Today, the education problems of these groups are an important problem to be considered. In this context, the awareness of the elementary school preservice teachers about this subject is important in order to take into account the educational needs of the children in this group. The aim of this study is to determine the opinions of the preservice teachers about the education process of the children in the disadvantaged group. The research is descriptive. The participants of the study are selected as the preservice teachers of the selected based on criterion sampling. Data were collected through structured interview form and analyzed by inductive analysis. The opinions of the preservice teachers about the education process with the disadvantaged groups were discussed within the framework of the themes of family, children, institution / persons and teaching activities.

Key Words: Disadvantaged Groups, Children At Risk, Elemantary School Preservice Teacher

\section{Giriş}

Insanın sosyal bir varlık olması bir toplum içerisinde yaşamasını gerektirir. Ancak toplum içerisinde bir arada yaşayan insanlar her zaman aynı koşullara sahip değildir. Bu durum kimi insanların bir takım kaynaklara ulaşmasını engellemektedir. Farklı nedenlerden kaynaklı olarak gereksinim duyduğu kaynaklara ulaşamayan bireyler ya da gruplar toplum içerinde kendisini dezavantajlı olarak görmektedir. Bireylerin ya da grupların içinde bulunduğu dezavantajlı olma durumu onların zaman zaman toplumdan ötekileştirilmesine

\footnotetext{
*Bu çalışma I. Uluslararası Bilim ve Eğitim Kongresinde sözlü bildiri olarak sunulmuştur.

** Ömür GÜRDOĞAN BAYIR, Dr. Öğr. Üyesi, Anadolu Üniversitesi, ogurdogan@anadolu.edu.tr, ORCID: orcid.org/00000002-7455-7237
} 
neden olabilir. Dezavantajlı olma durumu ise sosyal, ekonomik, kültürel gibi farklı birçok ölçüte göre farklı tanımlar içerebilir.

Dezavantajlı gruplar içerisinde bulundukları toplumun ekonomik, sosyal, kültürel vb. kaynaklarını kullanma bakımından eksik kalan ya da eksik bırakılan gruplar olarak tanımlanabilir. Ancak kimlerin dezavantajlı grup olduğu toplumdan topluma farklılık gösterebilir (Doğu Marmara Kalkınma Ajansı, 2011). Dezavantajlı grupları yalnızca cinsiyet, ırk, etnik grup ve yoksulluk kavramları ile ilişkili değildir. Dezavantajlı olma durumu kişinin kendisi için gerekli olan şeylere ulaşama durumuyla açıklanabilir. Bunlar özerklik, sorumluluk, öz saygı, kamu desteği, sağlık, eğitim, bilgi edinme, iş vb. olabilir. Dezavantajlı gruplar ırk, cinsiyet ve yoksulluktan daha fazla sınırlılıkla karşı karşıyadır. Bu grupların karşılaştıkları bazı sınırlılıklar daha kolay aşılabilir. Bazı sınırlıklar ise öz-yeterlilikle ilişkilidir ve bunların çözümü gruptan gruba değişiklik gösterir. Özellikle öz-yeterlilikle ilgili sorunların çözümünde bağımsızlık, özendirme, karar verme, öz-saygı, kamu desteği, sağlık, eğitim ve bilgilendirme gibi durumlar yatmaktadır (Mayer, 2003). Bu nedenle, bu sorunların çözümü gerekli olan durumlar incelendiğinde bir takım beceri ve değerleri de edindirmesi bakımından eğitim ön plana çıkmaktadır.

Dezavantajlı gruplar için eğitim ve öğretim hemen hemen bütün ülkelerin önemli bir ilgi ve sorun alanını oluşturmaktadır. Bu bireylerin eğitim ve öğretim gibi etkinliklerden uzaklaşması ekonomik ve sosyal süreçlere zarar vermektedir (UNESCO, 1997). Dezavantajlı gruptaki öğrencilerin eğitimi üzerinde önemle durulması gereken konular arasında yer almaktadır. Cap \& Mares (2007) öğretmenlerin bu öğrenci grubunun eğitiminde öğrencilerin yeteneklerine göre bilgi ve beceri kazandırmada, onların ilgi, tutum ve yeteneklerini geliştirmede önemli bir rol oynadığını belirtmektedir (Safrankova \& Zatapkova, 2017). Öğretmenlerin sınıf içerisinde karşılaşabileceği dezavantajlı grupta yer alan çocuklar şöyle ele alınabilir:

- Mülteci çocuklar: Mülteci zulüm, savaş ya da şiddetten dolayı ülkesinden kaçmaya zorlanan kişi olarak tanımlanabilir (UNHCR, Tarihsiz). Tüm dünyada birçok insan çatışma, doğal afet, insan haklarının ihlal edilmesi gibi birçok nedenden kaynaklı olarak başka ülkelere sığınmak durumundadır (Çakran \& Eren, 2017). Mülteciler yeni geldikleri ortamda bir takım zorluklarla karşı karşıyadır. Ancak çocuklar için bu durum daha da zordur (Yavuz \& Mızrak, 2016). Çocuklar kaçırma, silahIı gruplar, toplumsal cinsiyet gibi durumlara karşı nitelikli ve güvenli bir eğitimle korunabilir. Ancak eğitim sürecinde maddi sorunlara ek olarak nitelikli öğretmen bulmak, sınıfların kalabalık olması ve eğitim dili önemli diğer önemli sorunları oluşturmaktadır (Ferris \& Winthrop, 2010). 
- Engelli çocuklar: Doğuştan ya da sonrada herhangi bir hastalık ya da kaza sonucunda normal yaşamın gerektirdiği durumlara uymakta güçlük yaşayan, bedensel, zihinsel, ruhsal, sosyal ve duyusal yetilerini kaybetmiş kişiler engelli bireyler olarak tanımlanmaktadır (Demir \& Aysoy, 2002). Zihin, görme, işitme, ortopedik gibi engel türü bulunan bireylerin eğitim alması onların mümkün olduğu bağımsızlaşmalarında ve toplumsal yaşamın tüm alanlarına katılımında önemli bir role sahiptir (Şişman, 2014). Özel eğitim uygulamalarıyla birlikte engelli çocukların normal okullarda akranlarıyla bir arada eğitim görmeleri öğretmenlerin bu konuda eğitim görmelerini gerektirmektedir.

- Parçalanmış aile çocukları: Ölüm, anne ya da babanın uzun süreli evden ayrılmaları, boşanmaları ya da çocukların aileden ayrılması gibi durumlarda ortaya çıkan aile yapısı parçalanmış aile olarak tanımlanabilir (Özgüven, 2001). Parçalanmış ailelerde çocukların ruhsal açıdan etkilendiği ve birçok sorunun olduğu araştırmalarca ortaya konulmuştur. Bu nedenle öğretmenlerin bu durumdaki çocukların sağlıklı biçimde yetişmesi için bu konuda velileri yönlendirme, öğrencileri etkin kılacak görevler verme vb. (Herdem \& Bozgeyikli, 2013) noktalarda bilgi sahibi olması önem taşımaktadır.

- Çocuk işçiler: Aile bütçesine katkı sağlamak ya da kendi hayatını kazanmak amacıyla çalışma hayatında yer alan 18 yaşın altındaki bireyler çalışan çocuk ya da çocuk işçi olarak tanımlanmaktadır (Kolk \& Tulder, 2002'den akt. Fidan, 2004). Mevsimlik tarım işçilerinin çocukları da koşulları gereği aileleri ile birlikte çalışmaktadır. Bu çocukların da eğitimden uzaklaşmaları bir sorun durumunu oluşturmaktadır. Mevsimlik işçi çocukları bu dönemlerde okula gidememekte ve devamsızlık yapmaktadır (Karaman \& Yılmaz, 2011). Çalışan çocuk hemen hemen tüm toplumlarda çözüm bekleyen sosyal sorunlar arasında yer almaktadır. Çocuklar iktisadi nedenler, sosyal nedenler ve kişisel nedenlerden kaynaklı olarak çalışmaya başlamaktadır. Çalışan çocuklar içinde bulunduğu durumdan kaynaklı olarak okula karşı ilgisizlik göstermekte ve okuldan ayrılmayı bir seçenek olarak görmektedir (Fidan, 2004). Eğitim çalışan çocukların yaşam koşullarının iyileştirilmesinde önemli bir rol oynar. Öğretmenler bu çocuklar için öğrenmeyi çekici hale getirmeli, çocukların sorunları ile ilgilenmeli ve çocuk işçiliği konusunda bilgilendirme yapmalıdır. Bu nedenle, öğretmen önce çalışan çocukları belirlemeli, daha sonra onların devam durumu, başarı düzeyi, derse katılımı vb. durumları izlemelidir (Gülcan, Tarihsiz).

- Çocuk ihmali ve istismarına uğrayan çocuklar: Dünya Sağlık Örgütü, çocuk ihmal ve istismarını yetişkin, bir ülke ya da toplumun bilerek ya da bilmeden çocuğun sağlığını, fiziksel ve psikososyal gelişimini olumsuz yönde etkileyen davranışlar sergilemesi biçiminde tanımlar (Yakut \& Korkmaz, 2013). Fiziksel, cinsel ve duygusal olmak üzere üç türü bulunmaktadır. Yetişkinlerin çocuğa olan en temel sorumluluklarını yerine getirmemesi ise çocuk ihmali kapsamında ele alınabilir (Aral 
Ömür GÜRDOĞAN BAYIR

\& Gürsoy, 2001). Eğitim kurumları ve öğretmenler bu tür durumların tanımlanmasında ve önlenmesinde önemli görevler üstlenmektedir. Bu nedenle, öğretmenlerin bu konuya ilişkin eğitim almaları gerekmektedir (Pekdoğan \& Bozgün, 2018).

Öğretmenler sınıflarında sözü edilen bu durumların dışında dezavantaja sahip öğrencilerle karşılaşabilirler. Yoksullukla mücadele eden çocuklar, suç işleyen çocuklar, madde bağımlısı çocuklar yine karşılaşılabilecek gruplar arasında yer almaktadır. Bu nedenle, öğretmenlerin dezavantaja sahip çocukları nasıl eğitim sürecine dahil edeceğine ilişkin bilgi sahibi olması önemlidir.

Öğretmenler sınıflarındaki dezavantaja sahip çocukları en iyi bilenlerdir. Bu çocuklar genellikle devamsızlık yapar, yorgunluk işaretleri verirler. Ayrıca okul performansı düşük olan bu çocukların aile içi sorunları da bulunmaktadır. Bu çocukları belirleme, eğitime geri dönmelerini sağlama ve başarı durumlarını izleme öğretmenlerin yapabilecekleri arasında yer alır (Gülcan, Tarihsiz). Bu nedenle, öğretmenlere hizmet öncesi ve hizmet içinde buna yönelik eğitimlerin verilmesi, öğretmenlerin farkındalıkları artırmak ve onların bu konudaki eğitim gereksinimleri belirlemek anlamında araştırmaların yapılması önem taşımaktadır.

Alanyazında dezavantajlı gruptaki çocuklara yönelik yapılmış çeşitli araştırmalar bulunmaktadır. Bu kapsamda alanyazında mülteci çocuklar (Şeker \& Aslan, 2015; ArdıçÇobaner, 2015; Kağnıcı, 2017), çocuk işçiler (Şen \& Kahraman, 2012; Gülçubuk, 2012; Efe \& Uluoğlu, 2015), engelli çocuklar (Özşenol ve diğerleri, 2003; Temel, 2000; Artan, 2014) gibi çeşitli dezavantaja sahip çocuklara yönelik araştırmaların olduğu belirlenmiştir. Buna göre alanyazında sınıf öğretmeni adaylarının dezavantajlı gruplarla eğitim sürecini nasıl ele aldıklarına ilişkin bir çalışmaya rastlanmamıştır. Bu bağlamda bu araştırmanın amacı sınıf öğretmeni adaylarının dezavantajlı grupta yer alan çocukların eğitim sürecine ilişkin görüşlerini ortaya çıkarmaktır.

\section{Yöntem}

\subsection{Araştırmanın Modeli}

Sınıf öğretmeni adaylarının dezavantajlı gruplarla eğitim sürecine ilişkin düşüncelerini ortaya koymayı amaçlayan bu araştırma nitel verilere dayalı betimsel bir araştırmadır. Bu nedenle bu araştırmada sınıf öğretmeni adaylarının konuya ilişkin görüşleri bütüncül bir biçimde ele alınmıştır. 


\subsection{Katılımcılar}

Araştırmanın katılımcıları amaçlı örnekleme türlerinden ölçüt örnekleme tekniği kullanılarak belirlenmiştir. Buna göre araştırmaya önceden belirlenmiş ölçütleri karşılayan durumların ele alınmasını sağlayan ölçüt örneklemeye (Yıldırım \& Şimşek, 2006) göre seçilmiş toplam 74 sınıf öğretmeni adayı katılmıştır. Bu araştırmada örneklemin belirlenmesinde ölçüt olarak demokrasi eğitimi ve çocuk haklarını dersini almış olma belirlenmiştir. Bu kapsamda araştırmaya katılan sınıf öğretmeni adaylarının 54'ü kadın, 20'si erkektir. Ayrı bu öğretmen adaylarının 39'u dördüncü sınıf, 35'i üçüncü sınıftır.

\subsection{Verilerin Toplanması ve Analizi}

Araştırmanın verileri araştırmacı tarafından açık uçlu anket aracılığıyla toplanmıştır. Rubin (1983) açık uçlu anketin yapılandırılmış görüşme teknikleri arasında yer aldığını belirtmektedir. Açık uçlu ankette bulunan soru setine bireyler öznel ve istediği biçimde yanıt vermektedir (Yıldırım \& Şimşek, 2006). Araştırmada kullanılan açık uçlu anket iki bölümden oluşmaktadır. Birinci bölümde kişisel bilgilere ilişkin sorulara yer verilmiştir. Anketin ikinci bölümünde ise sınıf öğretmeni adaylarının dezavantajlı gruplarla eğitim sürecine ilişkin görüşlerini belirlemeye yönelik sorular bulunmaktadır.

Araştırmada verilerin analizinde tümevarım analizinden yararlanılmıştır. Tümevarım analizi çalışılan konu kapsamında oluşturulan örüntülerden ortaya çıkan boyutları analiz etme olanağı sağlar (Patton, 2002). Bu kapsamda sınıf öğretmeni adaylarının görüşleri kodlanmış ve bu kodlar bir araya getirilerek temalar oluşturulmuştur.

Araştırmada verileri araştırmacı ve bir alan uzmanı ayrı ayrı analiz etmiştir. Daha sonra bir araya gelerek temalara son biçimi verilmiştir. Araştırmanın bulgularının sunumunda öğretmen adaylarının görüşlerinden doğrudan alıntılar yapılmıştır. Alıntıların verilmesinde öğretmen adaylarına verilen numaralar kullanılmıştır.

\section{Bulgular}

Araştırma kapsamında elde edilen bulgular aile, çocuk, kurum/kişiler ve öğretim etkinlikleri temaları çerçevesinde sunulmuştur.

\subsection{Aileye ilişkin bulgular}

Sınıf öğretmeni adayları dezavantajlı gruplarla eğitim sürecine ilişkin aile ile yapılabileceklere yer vermiştir. Buna göre sınıf öğretmeni adaylarının aileye ilişkin görüşleri Tablo 1 'de sunulmuştur. 
Ömür GÜRDOĞAN BAYIR

Tablo 1. Dezavantajlı Gruplarla Eğitim Sürecinde Aileye İlişkin Görüşler

\begin{tabular}{ll}
\hline \hline Aile & $f$ \\
\hline Aile görüşmeleri yapma & 48 \\
Ailelere eğitim verme & 5 \\
\hline
\end{tabular}

Tablo 1'de görüldüğü gibi, sınıf öğretmeni adayları dezavantajlı gruplarla eğitim sürecinde aileye ilişkin olarak ailelerle görüşme yapma ve ailelere eğitim verme konusunda görüş bildirmişlerdir. Bu konuda ailelerle görüşme yapmayı önemseyen öğretmen adaylarından biri bu görüşünü "Aileleriyle iletişime geçerim. En basit soru şu çocukların ailelerin yanında bulamayıp da sokaklarda kötü alışkanlıklarda bulduğu şey ne? Aile nerede hata yapıyor? (K10)" biçiminde açıklayarak ailelerin görüşünü almayı ön plana çıkarmıştır. Yine aynı şekilde ailelerle görüşme yapma konusunda görüş belirten öğretmen adayların biri ise bunu "Aile görüşmelerinin yapılması gerekiyor. Ancak öğretmen tek başına bu konuda yeterli olmayacaktır. Okul-aile-çevre-öğretmen işbirliği ile bu çalışmalar yapılmalıdır (K58)" biçiminde açıklayarak işbirliğine de dikkat çekmiştir. Ailelere bu konuda eğitim verilmesi gerektiğini düşünen öğretmen adaylarından biri bu görüşünü "Aileleri eğitim sürecinin içine alırdım. Önce kendim bu konuda gerekli eğitimleri aldıktan sonra mutlaka aileleri de bilgilendirirdim. Dezavantajlı gruptaki çocuklarla bu şekilde ilgilenmeye çalışırım (K45)" biçiminde açıklayarak önce kendisinin gerekli eğitimleri alması gerektiğinin altını çizmiştir. "Ailelere yönelik seminerler düzenlemeye çalışırım (K66)" biçiminde görüşlerini açıklayan öğretmen adaylarından bir diğeri ise yine aile eğitimini ön plana çıkarmıştır. Buna öğretmen adaylarının dezavantajlı gruplarla eğitim sürecinde ailenin rolünü önemsedikleri belirtilebilir.

\section{2. Çocuğa ilişkin bulgular}

Sınıf öğretmeni adayları dezavantajlı gruplarla eğitim sürecinde çocukla ilgili yapılabilecek bir takım noktalara da değinmiştir. Bu noktalar Tablo 2'de sunulmuştur.

Tablo 2. Dezavantajlı Gruplarla Eğitim Sürecinde Çocuğa İlişkin Görüşler

Çocuk f

Sorunun nedeni belirleme 14

Tanıma

Güven verme 
İlgi duyduğu alana yönlendirme

Eşit davranma

Eğitim verme

Model olma

Sorumluluk verme

Tablo 2'de görüldüğü gibi, sınıf öğretmeni adayları dezavantajlı gruplarla eğitim sürecinde çocuğa ilişkin yapılabilecekleri sorunun nedenini belirleme, çocuğu tanıma, çocuğa güven verme, çocuğu ilgi duyduğu alana yönlendirme, çocuklara eşit davranma, çocuğa eğitim verme, model olma ve çocuğa sorumluluk verme ile açıklamışlardır. Dezavantajlı gruplardaki çocuklarla eğitim sürecinde dezavantaj durumunu belirlemenin ve bunun altında yatan nedenlerin önemli olduğunu düşünen öğretmen adaylarından biri bu görüşünü "Sınıfımda ya da çevremde bu tür çocuklar bulunduğunda öncelikle bu durumlara nelerin neden olduğunu araştırırım. Nedenini bulduktan sonra çözüme ilişkin neler yapabileceğimi düşünür ve gerekli birimlere başvururum (K3)" biçiminde açıklamıştır. Yine bu konunun önemine dikkat çeken diğer bir öğretmen adayı ise görüşünü "Onların bu eğilimleri neden tercih ettiklerini, hangi koşullar altında yaşadıklarını, tercihlerini öğrenerek bundan sonra nasıl çözüm yollarına gidilmesi gerektiğini düşünürüm (K15)" biçiminde açıklamıştır. Çocukları tanımanın önemini vurgulayan öğretmen adaylarından bir diğeri ise görüşünü "Çocukların sevdiği ve sevmediği şeyleri tanımaya çalışırım. Sinirlendiği ya da üzüldüğü zaman yapabileceği bir eylem belirleyip onu yapmasını sağlarım. Tabi bunları çocuğu tanıyarak yapabilirim. Böylece ilgisini çekebilecek durumları hazırlayarak eğitim sürecinde kalmasını önemserim (K2)" biçiminde belirterek çocuğun ilgilerinin eğitim süreci açısından önemine değinmiştir. Yine aynı öğretmen adayı "ilgisini farklı alanlara çekmeye çalışırım. Spor, el işleri, resim, müzik gibi konulara yönlendirme yaparım” biçiminde ifadeler kullanarak çocukların durumlarını ele almıştır. "ilk olarak çocukla aramdaki bağı artırır, bana güvenmesini sağlarım. Karşılıklı bir ilişki kurmaya çalışırım (K34)” biçiminde görüşlerini açıklayan öğretmen adayı ise çocuğun öğretmenine güven duyması gerektiğinin altını çizmiştir. "Bu durumda olan çocuklar sosyal ortamdan dışlanmamalıdır. Diğer çocuklara olduğu gibi bu çocuklara da eşit davranılmalıdır (K1)" biçiminde görüş bildiren öğretmen adayı ise eşitlik ilkesini ön plana çıkarmıştır. Buna göre sınıf öğretmeni adaylarının dezavantajlı gruptaki çocuklarla eğitim sürecinin nasıl olması gerektiğini yine bu durumdaki çocuktan başlayarak açıkladıkları söylenebilir. 
Ömür GÜRDOĞAN BAYIR

\subsection{Kurum/Kişilere ilişkin bulgular}

Sınıf öğretmeni adayları dezavantajlı gruplardaki çocuklarla olan eğitim sürecinde farklı kurum/kişilerle işbirliği yapılması gerektiğini ifade etmiştir. Bu kapsamda sınıf öğretmeni adaylarının kurum/kişilere ilişkin görüşleri Tablo 3'te sunulmuştur.

Tablo 3. Dezavantajlı Gruplarla Eğitim Sürecinde Kurum/Kişilere İlişkin Görüşler

\begin{tabular}{ll}
\hline \hline Kurum/Kişiler & $f$ \\
\hline Rehber öğretmene başvurma & 22 \\
Gerekli kurumlara başvurma & 21 \\
Yakın çevreyi tanıma & 3 \\
\hline
\end{tabular}

Tablo 3'te görüldüğü gibi sınıf öğretmeni adayları kurum/kişiler kapsamında rehber öğretmene başvurma, gerekli kurumlara başvurma ve yakın çevreyi tanımayı önemsemişlerdir. Buna göre rehber öğretmene başvurmanın önemini ifade eden sınıf öğretmeni adaylarından biri bu görüşünü "Bu çocukların sergiledikleri davranışlar konusunda bilgi edinmek için rehber öğretmene başvurmak önemlidir (K6)" biçiminde açıklayarak alan uzmanın görüşlerini önemsediğini göstermiştir. Rehber öğretmenin görüşlerine başvurmayı önemseyen diğer bir öğretmen adayı ise bu görüşünü "Rehberlik hizmetlerinin görüşlerinin alınması gerekmektedir (K52)" biçiminde ifade etmiştir. "Bir çocuğu kazanmak ya da kaybetmek çok hassa bir konu. Özellikle dezavantajlı bir çocuğa yaklaşmak daha zor. Bu konuda yetkili olanlarla hareket ederim. Çünkü böyle bir durumda tek başına hareket etmenin doğru olmadığını düşünüyorum (K18)" biçiminde görüş bildiren öğretmen adayı işbirliğinin önemini ifade etmiştir. Yine farklı kişilerle işbirliğini öngören başka bir öğretmen adayı ise bu görüşünü "Dezavantajlı bir çocukla karşılaşmam durumunda profesyonel bir yardım almanın doğru olduğuna inanırım (K28)" biçiminde açıklamıştır. Sınıf öğretmeni adaylarından bir diğeri ise yakın çevreyi tanımanın gerekli olduğunu düşünerek bunu "Çevreyi iyi tanımak gerekir (K1)" biçiminde açıklamıştır. Buna göre öğretmen adaylarının dezavantajlı çocuklarla eğitim sürecinde farklı kurum ya da kişilerin işe koşulması gerektiğini ele aldıkları söylenebilir.

\section{4. Öğretim etkinliklerine ilişkin bulgular}

Sınıf öğretmeni adayları dezavantajlı gruplardaki öğrencilerle eğitim sürecinde öğretim etkinlikleri kapsamında neler yapabileceklerine de değinmişlerdir. Bu kapsamda öğretmen adaylarının görüşleri Tablo 4'te sunulmuştur. 
Tablo 4. Dezavantajlı Gruplarla Eğitim Sürecinde Öğretim

Etkinliklerine İlişkin Görüşler

\begin{tabular}{ll}
\hline \hline Öğretim etkinlikleri & $f$ \\
\hline Farklı alanlarda etkinlikler yapma & 11 \\
Materyallerden yararlanma & 10 \\
Sınıfa uzman çağırma & 3 \\
Bireyselleştirilmiş eğitim planı hazırlama & 2 \\
\hline
\end{tabular}

Tablo 4'te görüldüğü gibi, sınıf öğretmeni adayları öğretim etkinlikleri kapsamında farklı etkinlikler yapma, materyallerden yararlanma, sınıfa uzman çağırma ve bireyselleştirilmiş eğitim planı hazırlamayı önemsemişlerdir. Bu kapsamda farklı alanlarda etkinlikler yapılması gerektiğini düşünen öğretmen adaylarından biri bu görüşünü "Kalabalık sınıflarda yapmak zor olsa da bol bol eğlenceli ve her çocuğa hitap eden farklı etkinlikler düzenlemeliyiz (K11)" biçiminde belirterek farklı alanlardaki etkinliklerin çocuklara hitap edebileceğini ele almıştır. "Çocuklara bir şeyler yalnızca düz anlatım yoluyla telkin edilmemelidir. Başka etkinlikler mutlaka yapılmalıdır (K12)" biçiminde görüşlerini açıklayan öğretmen adayı da benzer görüşlerin altını çizmiştir. Öğretim sürecinde farklı materyallerden yararlanılması gerektiğini düşünen öğretmen adayı bunu "Dezavantajlı gruptaki çocuklara mesaj vermek için örnek olaylar, videolar ve çizgi filmlerden yararlanılmalıdır (K25)" biçiminde açıklamıştır. Uzman çağırmanın etkili olabileceğini düşünen öğretmen adaylarından biri bu görüşünü "Sınıfa alanında uzman bir kişi davet edilerek onunla sohbetler yapılmalıdır (K5)" biçiminde açıklamıştır. "Bireyselleştirilmiş eğitim planı hazırlamaIıyım eğer dezavantaj durumu engel ise (K17)" biçiminde görüş bildiren öğretmen adayı ise engelleri ele almıştır. Buna göre öğretmen adaylarının dezavantajlı öğrencilerle eğitim sürecinde öğretme-öğrenme sürecinin de önemli olduğunu düşündükleri söylenebilir.

\section{Sonuç, Tartışma ve Öneriler}

Araştırma sınıf öğretmeni adaylarının dezavantajlı gruplardaki çocuklarla eğitim sürecine ilişkin düşüncelerini ortaya çıkarmayı amaçlamıştır. Sınıf öğretmeni adaylarının bu konuya ilişkin düşünceleri aile, çocuk, kurum/kişiler ve öğretim etkinlikleri çerçevesinde ele alınmıştır. Buna göre sınıf öğretmeni adayları dezavantajlı gruptaki çocuklarla eğitim sürecini farklı boyutları ele alarak açıklamıştır.

Sınıf öğretmeni adayları dezavantajlı çocuklarla eğitim sürecinde ailenin önemini dile getirmişlerdir. Bu kapsamda ailelerle görüşme yapma ve ailelere eğitim vermeyi önemsemişlerdir. Cinsiyet, dil, din, sağlık durumu, yerleşim yeri gibi özelliklerden kaynaklı olarak dezavantajlı grupta yer alana çocuklara bu koşullarından bağımsız olarak gereksinimlerini karşılayacak biçimde eğitimlerin verilmesi kapsayıcı eğitim olarak ele alınmaktadır 
Ömür GÜRDOĞAN BAYIR

(Oral, 2016). Kapsayıcı eğitim kapsamında da veli desteğini almak büyük önem taşımaktadır. Ayrıca bu eğitimde okul dışı hayatları ile okuldaki eğitim arasında ilişki kurmak için de velilerden katkı almak gerekir (Ayan-Ceyhan, 2016). Dolayısıyla sınıf öğretmeni adaylarının bu konuda aileye verdiği önem dezavantajlı grupları içine alan kapsayıcı eğitim uygulamalarının gereklilikleri ile uyuşmaktadır. Önder \& Güçlü (2014) tarafından yapılan araştırmada çocukların dezavantajlılık durumunu azaltmada aile eğitimlerinin önemli olduğu sonucuna ulaşılmıştır. Araştırmada ortaya çıkan bu sonuç sınıf öğretmeni adaylarının aile eğitimi ile ilgili görüşlerini destekler niteliktedir.

Sınıf öğretmeni adayları eğitim sürecinde dezavantajlı çocukların kendilerine ilişkin yapılabilecekleri sorunun nedenini belirleme, çocuğu tanıma, çocuğa güven verme, çocuğu ilgi duyduğu alana yönlendirme, çocuklara eşit davranma, çocuğa eğitim verme, model olma ve çocuğa sorumluluk verme biçiminde açıklamışlardır. Bu kapsamda sınıf öğretmeni adayları öncelikle bu çocukların kendisinin önemsenmesi gerektiğini düşünmektedirler. Kapsayıcı eğitim doğrultusunda ele alınan noktalardan biri de öğretmen-öğrenci iletişimidir. Ayan-Ceyhan'ın (2016) yaptığı araştırmada öğretmenlerin çocukları fazla tanımadıklarını belirttikleri ancak çocuğu tanıyınca bir şeyler inşa edebileceklerini ifade ettikleri bulunmuştur. Bu durum öğretmen adaylarının çocukları tanıma konusundaki görüşleriyle paralellik göstermektedir. Savi-Çakar \& Yazıcı-Okuyan'ın (2017) yaptığı araştırmada da öğretmen adaylarının çocuklara eğitim vermeyi ve çocuklara model olmayı ele aldıkları ortaya çıkmıştır. Mülteci çocukları ele alan bir çalışmada da öğretmenlerin bu öğrencileri desteklemesi gerektiği ifade edilmiştir (Şeker \& Aslan, 2015).

Sınıf öğretmeni adayları dezavantajlı gruptaki çocuklara etkili eğitimler verebilmek için kurum/kişilerle işbirliği yapılması gerektiğini düşünmektedirler. Bu kapsamda rehber öğretmene başvurma, gerekli kurumlara başvurma ve yakın çevreyi tanıma konularını ele almışlardır. Savi-Çakar \& Yazıcı-Okuyan'ın (2017) çocuk ihmali ve istismarı konusunda öğretmen adayları ile yaptığı araştırmada öğretmen adaylarının rehber öğretmene başvurma, polise haber verme vb. konularda görüş belirttiği ortaya çıkmıştır. Zaten öğretmenlerin çocuk ihmali ve istismarı gibi konuları belirledikten sonra bildirim yapmaları gerekir (Walsh ve diğerleri, 2005). Ayrıca Herdem \& Bozgeyikli (2013) tarafından yapılan araştırmada da sınıf öğretmenlerinin anne babaları çocuklarına nasıl davranacakları konusunda rehber öğretmene yönlendirmelerine ilişkin öneriler getirmişlerdir. Bu bağlamda bu araştırma sonucunda da görüldüğü gibi öğretmen adayları farklı kurum ve kişilerle işbirliğini önemsemektedir.

Sınıf öğretmeni adayları dezavantajlı gruptaki çocuklarla eğitim sürecinde öğretmeöğrenme sürecinin etkili hale getirilmesi gerektiğini düşünmektedirler. Bunu farklı etkinlikler yapma, materyallerden yararlanma, sınıfa uzman çağırma ve bireyselleştirilmiş eği- 
tim planı hazırlama konularına değinerek ele almışlardır. Kapsayıcı eğitim etkinlikleri doğrultusunda tüm öğrencilerine gereksinimlerine yanıt verecek yöntemlerin kullanılması ve farklılaştırılmış materyallerin kullanılması gerekmektedir (Oral, 2016). Ayrıca yine bu etkinlikler kapsamında kullanılabilecek materyaller olan film, görsel ve metinlerden bir havuz oluşturulması gerektiğine ilişkin araştırma bulgusu mevcuttur (Ayan-Ceyhan, 2016). Bu durum sınıf öğretmeni adaylarının farklı etkinlikler yapma ve materyaller kullanma görüşünü desteklemektedir. Bireyselleştirilmiş eğitim planı kaynaştırma yoluyla eğitim alan çocuklar için hazırlanması gerekmektedir (Sart ve diğerleri, 2016). Dolayısıyla engelli çocukları dezavantajlı gruplar kapsamında ele alan sınıf öğretmeni adaylarının öğretmeöğrenme sürecine ilişkin ifade ettiği bu durum yapılması gerekenler arasında yer almaktadır.

Dezavantajlı grupların eğitim sürecinde okullar için bir tehdit olarak görüldüğü yöneticiler tarafından belirtilen bir araştırmada göçle gelen öğrenciler, engelli çocuklar, çocuk işçiler, madde bağımlısı çocuklar, aile bütünlüğü bozulmuş çocuklar vb. bu kapsamda ele alınmıştır. Bu grupların tehdit olarak eğitimsel açıdan zayıf olması ve eğitimde fırsat eşitliğinden yararlanamamasıdır. Bu durum da eğitim sürecinde başarının düşmesine neden olmaktadır (Özan ve diğerleri, 2015). Bu durumda dezavantajlı çocuklarla eğitim sürecinin iyileştirilmesi eğitimde başarının yükselmesi açısından da önem taşımaktadır.

Sonuç olarak günümüz koşulları dikkate alındığında sınıf öğretmenlerinin eğitim sürecinde dezavantajlı gruplarda yer alan çocuklarla karşılaşma olasılığı artmaktadır. Savaş ve çatışma nedeniyle göçün artması, sosyoekonomik duruma bağı olarak çocukların çalışması ya da yine çatışma ortamında ihmal ve istismara uğraması gibi nedenler sınıf öğretmeni adaylarının bu konulara ilişkin bilgi sahibi olmasını zorunlu kılmaktadır. Ancak yapılan araştırmada sınıf öğretmeni adaylarının bu konuları yüzeysel olarak ele aldıkları görülmüştür. Öğretmen adayları bu konuya ilişkin olarak aileleri ön plana çıkarmışlardır. Bu kapsamda araştırma sonucunda şu önerilere yer verilebilir:

- Eğitim fakültelerinde bu konulara yönelik etkinlikler gerçekleştirilmelidir.

- Bu konuya yönelik seçmeli ya da zorunlu dersler konulabilir.

- Bu konu hakkında derinlemesine çalışmalar yapılabilir.

- Öğretmen adaylarının bu yöndeki ihtiyaçları belirlenebilir.

\section{Kaynaklar}

Aral, N., \& Gürsoy, F. (2001). Çocuk hakları çerçevesinde çocuk ihmal ve istismarı. Milli Eğitim Dergisi, 151(5).

Ardıç Çobaner, A. (2015). Çocuk hakları bağlamında Suriyeli mülteci çocukların haberlerde temsili. Marmara Iletişim Dergisi, 24, 27-54. 
Ömür GÜRDOĞAN BAYIR

Artan, i. (2014). Engelli çocukların eğitiminde etkili bir teknik: Müzik. Gazi Üniversitesi Gazi Eğitim Fakültesi Dergisi, 21(2).

Ayan-Ceyhan, M. (2016). Kapsayıcı eğitim: okul pratikleri, öğretmen ihtiyaçları. ERG. http://www.egitimreformugirisimi.org/wp-

content/uploads/2017/03/ERG_KapsayiciEgitim_Ogretmenlhtiyaclari.pdf adresinden 06.12.2018 tarihinde edinilmiştir.

Demir, Ö. \& Aysoy M. (2002). Engelli tanımı ve sınıflaması. Türkiye Özürlüler Araştırması. Devlet İstatistik Enstitüsü.

Doğu Marmara Kalkınma Ajansı. (2011). Dilovası'nda dezavantajlı grupların istihdam potansiyelinin artırılması: Araştırma sonuç raporu. Marka Yayınları Serisi.

Efe, H. \& Uluoğlu, S. A. (2015). Dünyada çocuk işçiliğiyle mücadelede gelinen nokta ve geleceğe dair bazı öngörüler. Eğitim Bilim Toplum, 13(51), 46-72.

Eren, V. \& Çakran, Ş. (2017). Mülteci politikası: Avrupa birliği ve Türkiye karşılaştırması. Mustafa Kemal Üniversitesi Sosyal Bilimler Enstitüsü Dergisi, 14(39), 1-30.

Ferris, E. \& Winthrop, R. (2010). Education and displacement: Assessing conditions for refugees and internally displaced persons affected by conflict. UNESCO: Background paper for the EFA Global Monitoring Report.

Fidan, F. (2004). Çalışan çocuk olgusuna sosyo- psikolojik bakış. Trakya Üniversitesi Sosyal Bilimler Dergisi, 4(1), 30-49.

Gülcan, M. (Tarihsiz). Çocuk işçiliği ve eğitim: öğretmen el kitabı. Çalışma ve Sosyal Güvenlik Bakanlığı.

Gülçubuk, B. (2012). Tarımda çocuk emeği sömürüsü ve toplumsal duyarlılık. Çalışma ve Toplum, 33(2).

Herdem, F. S. \& Bozgeyikli, H. (2013). İlköğretime devam eden parçalanmış ve tam aile çocuklarının rehberlik ihtiyaçlarının karşılaştırmalı olarak incelenmesi, OPUS-Türkiye Sosyal Politika ve Çalışma Hayatı Araştırmaları Dergisi, 3(4) s.7-35.

Kağnıcı, D. Y. (2017). Suriyeli Mülteci Çocukların Kültürel Uyum Sürecinde Okul Psikolojik Danışmanlarına Düşen Rol ve Sorumluluklar. Ilköğretim Online, 16(4). 
Karaman, K. \& Yılmaz, A. S. (2011). Mevsimlik tarım iş̧̧ileri ve enformel ilişkiler ağı: Giresun'da çalışan mevsimlik tarım işçileri üzerine bir araştırma. Zeitschrift für die Welt der Türken/Journal of World of Turks, 3(1), 211-226.

Mayer, S. E. (2003). What is a disadvantage groups. 29.11 .2018 tarihinde https://studylib.net/doc/8720705/what-is-a-\%E2\%80\%9Cdisadvantagedgroup\%3F\%E2\%80\%9D adresinden edinilmiştir.

Oral, I. (2016). Türkiye'de kapsayıcı eğitimi yaygınlaştırmak için politika önerileri. ERG. http://www.egitimreformugirisimi.org/wpcontent/uploads/2017/03/ERG_KapsayiciEgitim_PolitikaOnerileri.pdf adresinden 06.12.2018 tarihinde edinilmiştir.

Önder, E. \& Güçlü, N. (2014). İlköğretimde okullar arası başarı farklılıklarını azaltmaya yönelik çözüm önerileri. Eğitim Bilimleri Dergisi, 40, 109-132.

Özan, M. B., Şener, G., Polat, H., \& Yaraş, Z. (2015). Eğitim sektöründe swot analizi: Elazığ ili örneği. Harput Araştırmaları Dergisi, 2(1), 125-148.

Özgüven, i.E. (2001). Ailede iletişim ve yaşam. Ankara: PDREM Yayıncılık.

Özşenol, F., Işıkhan, V., Ünay, B., Aydın, H. İ., Akın, R., \& Gökçay, E. (2003). Engelli çocuğa sahip ailelerin aile işlevlerinin değerlendirilmesi. Gülhane Tıp Dergisi, 45(2), 156164.

Pekdoğan, S. \& Bozgün, K. (2018). Öğretmenlerin Çocuk ihmali ve istismarı hakkındaki görüşlerinin incelenmesi. MANAS Sosyal Araştırmalar Dergisi, 7(2), 433-443.

Safrankova, A. P. \& Zatopkova, K. (2017). Teachers'evaluatıon of ımportance of selected determınants of education of socially dısadvantaged pupıls. Journal on Efficiency and Responsibility in Education and Science, 10(1), 24-33.

Sart, H. Z., Barış, S. , Düşkün, Y. \& Sarışık, Y. (2016). Engelli çocukların Türkiye'de eğitime erişimi: durum analizi ve öneriler. ERG. http://www.egitimreformugirisimi.org/wp-content/uploads/2017/03/ERG_EngeliOlan-\%C3\%87ocuklar\%C4\%B1n-T\%C3\%BCrkiyede-E\%C4\%9Fitime-Eri\%C5\%9Fimi.pdf adresinden 04.12.2018 tarihinde edinilmiştir.

Şeker, B. D. \& Aslan, Z. (2015). Eğitim sürecinde mülteci çocuklar: Sosyal psikolojik bir değerlendirme. Kuramsal Eğitimbilim Dergisi, 8(1), 86-105. 
Şen, B. \& Kahraman, F. (2012). Oyun hakkının uzağında yaşamak: Türkiye'de içgöç ve çocuk emeği. SDÜ Fen Edebiyat Fakültesi Sosyal Bilimler Dergisi, 27, 167-189.

Şişman, Y. (2014). Engelliler açısından eşitlik, ayrımcılık ve eğitim hakkı. Sosyal Politika Çalışmaları Dergisi, 14(32), 57-85.

Temel, Z. F. (2000). Okul öncesi eğitimcilerinin engellilerin kaynaştırılmasına ilişkin görüşleri. Hacettepe Üniversitesi Eğitim Fakültesi Dergisi, 18(18).

UNESCO (1997). Alternative education strategies for disadvantaged groups. Paris: International Institute for Educational Planning.

UNHCR. (Tarihsiz). What is a refugee. 29.11. 2018 tarihinde https://www.unrefugees.org/refugee-facts/what-is-a-refugee/ adresinden edinilmiştir.

Walsh, K., Farrell, A., Schweitzer, R. \& Bridgstock, R. (2005). Critical factors in teachers' detecting and reporting child abuse and neglect:Implications for practice. https://eprints.qut.edu.au/777/1/ACT_Complete_Report.pdf adresinden 05.12.2018 tarihinde edinilmiştir.

Yakut, H. i. \& Korkmaz, E. (2013). Çocuklarda cinsel istismar. Jinekoloji-Obstetrik ve Neonatoloji Tıp Dergisi, 10(39), 1630-1632.

Yavuz, Ö. \& Mızrak, S. (2016). Acil durumlarda okul çağındaki çocukların eğitimi: Türkiye'deki Suriyeli mülteciler örneği. Göç Dergisi, 3(2), 175-199.

Yıldırım, H. \& Şimşek, A. (2006). Sosyal bilimlerde nitel araştırma yöntemleri. Beşinci Baskı. Ankara: Seçkin Yayınevi 